\title{
Civil service and the challenge of productivity in Nigeria
}

\author{
Rabi'u Muhammad Ishaq \\ Shehu Shagari College of Education, Sokoto, Sokoto State, Nigeria \\ E-mail address: kamarfama@yahoo.com
}

\begin{abstract}
A key challenge facing the country in general is how to ensure the socio-economic and political development of the citizenry. Development, in all its facets, has remained a mirage in spite of the favourable human and material resources endowment of the country. This paper focuses on the role of the civil service against the growing expectations of the public. It looks at the 'political' context within, which the civil service operates and argues that positive cooperation or 'organic solidarity', to quote Durkheim, is necessary if the general and specific development objectives of Nigeria are to be achieved. A number of interrelated issues are addressed. What is the nature and impact of the civil service vis-àvis the drive toward development? What kind of cooperation must be forged between political office holders and career civil servants, on the one hand, and between them and the public, whose increasing expectations stare us at the face, on the other? What are the obstacles in the chosen task of harmonious working relationships between the two and what strategies could be developed to enhance such relations? What is emphasized here is the positive partnership of administrations and politicians in the quest for development.
\end{abstract}

Keywords: Civil-Service; Politicians; Partnership; Harmony; Development

\section{INTRODUCTION}

The civil service as is widely known is the government tool for the implementation of its policies and programmes. This remains the main function of the civil service. The question which continues to be asked by the leadership and the enlightened general public is how effective and committed the civil service is to its functions. This is notwithstanding the fact that there are some auxiliary factors like welfare and the prevailing societal conditions which may impact on the civil servant. It is an understatement to say that societal influence has been quite overwhelming in recent times. Quite a number of people in and outside government point to the good old days of the civil service. This gives the impression that they look forward to a return to those days, even though the circumstances have changed.

There seem to be not only growing poverty, unemployment and an ever widening gap between the rich and poor; but also the palpable decay of public institutions. Decades of Military authoritarian rule have significantly accounted for this. But what also cannot be contested is the role/complicity of both the political office holders and the civil service. This paper focuses on the role of the civil service against the growing expectations of the public. It looks at the 'political' context within, which the civil service operates and argues that positive cooperation or 'organic solidarity', to quote Durkheim (cited in Kamenka, et al, 1979), is 
necessary if the general and specific development objectives of Sokoto state are to be achieved. A number of interrelated issues are addressed. What is the nature and impact of the civil service vis-à-vis the drive toward development? What kind of cooperation must be forged between political office holders and career civil servants, on the one hand, and between them and the public, whose increasing expectations stare us at the face, on the other? What are the obstacles in the chosen task of harmonious working relationships between the two and what strategies could be developed to enhance such relations? What is emphasized here is the positive partnership of administrations and politicians in the quest for development. As key players in the task of governance, politicians and civil servants must be able to work together for the common good of all. Indeed, that must have been the main motivation for joining the service in the first place.

\section{THE CIVIL SERVICE AND ITS ROLE}

The civil service is at the centre of governmental activity. It is the epitome of rationality. Max Weber, a German sociologist of repute, delineated a number of important elements critical to the success of an ideal type bureaucracy. Six are described here: (i) there is the principle of fixed and official jurisdictional areas, which are generally ordered by rules, that is by law or administrative regulations. In other words, workers have official duties, must stay within their jurisdictional areas and must carry out those duties according to rules. (ii) The principles of office hierarchy and levels of graded authority. This means the presence of a strict chain of command or authority structure in which lower offices are supervised by the higher ones. (iii) The management of the modern office is based on written documents (files), which are preserved in their original or draft form. Every decision or action (recruitment, promotion, purchases, disengagement, etc), is recorded in writing. (iv) Hiring and promotion are based on individual's ability to do the job (or on merit). Nepotism is frowned at and relationships are impersonal. (v) Official activity demands the full working capacity of the official. Administrative work is a full time commitment; and (vi) The management of the office follows general rules or an established procedure covering just about everything (Mclntyre, 2002:121123). The presence of rational elements in any service is a major guarantor against personal or arbitrary rule. To what extent is the above elements found today in Nigeria Civil Service could best be answered by Nigerians.

There are a number of conditions that join with the above to ensure that the civil service meets the challenges of development. Foremost is a proper understanding of the realities within which the beneficiaries of the service offered live; where are they? How do they make a living? What things matter the most to them? What are the threats to their livelihood? What is their perception of 'government' - local, state, federal? A policy (intended for implementation by the civil service) must be clear, specific and thus unambiguous. The presence of good organization on ground with appropriate planning level is also a key requirement. Also, effective implementation of policies requires that adequate resources are made available just as the environment within which work has to take place need also be made conducive. An obvious implication of not attending to the above would result in policy implementation gap (PIG). In what ways, then, is the civil service central to governmental activities?

Three major roles of the civil service are discernible. First, it has the major task of translating into concrete actions the policies of political bodies. The civil service is the main instrument which government uses to regulate and manage all aspects of the economy of a society. It is the main medium through which all institutions obtain various types of approvals, 
licenses, permits, etc. Indeed, all institutions perforce have to deal with the civil service at one point or the other in their existence and operations. The degree to which socio-economic and political progress is attained is largely dependent or linked to the performance of the public service. Second, it has the important role of assisting in the formulation of policies, a role directly arising from the knowledge, experience and information at the disposal of civil servants. The notion of a strict dichotomy between administration and politics, always in dispute, is now facing further threats. Indeed, for Mills:

The executive bureaucracy (has) become not only the centre of power but also the arena within which and in terms of which all conflicts of power are resolved or denied resolution (Mills, 1964: 227).

Cooker concurs with the above, concluding further that "the notion of a powerless, instrumental, value-free, neutral, competent public bureaucracy no longer holds" (1982:169). Administration and policies are intertwined, notwithstanding the qualification often advanced, to the effect that there is more "politics" in the formation of public policy and more "administration" in the execution of same. In the real world, where results are central and failure of policy has important consequences, policy formulation and implementation are merged. A "policy" formulated without due regard to real problems of implementation fails. It sends negative signals about the "stupidity" of government announcing important policies of no practical value. On the other hand, in no real world situation could one successfully administer policies knowing nothing about the rationale for its formulation.

The importance of especially top civil servants in public policy formulation is captured by Grey Longe, a one time Head of Service of the Federation. He wrote that:

It is not true as is sometimes alleged that most permanent secretaries have reduced their ministers or commissioners to mere 'rubber stamps' What is of course true is that a permanent secretary who is worth his position is knowledgeable, experienced and so familiar with the civil service organization which exists to advise the minister and implement approved policies and programmes that when he makes submission to the minister they are in such a form that they can be approved completely or with minor amendment (cited in Bande, 1997:48).

Third, the civil service is critical to maintaining continuity of government policies and programmes. Governments change, often frequently through coups or periodic elections. Liman Ciroma, a former Head of Service and Secretary to the Government of the Federation wrote:

as soon as there was a change of government...we rallied round the Head of Service and took over; and continued as if nothing had happened, until the new people came and then we hand it over to them...(cited in Bande, 1997:45).

In Nigeria, so many kinds of such a transition have been witnessed; from 1966 to 2011. 


\section{THE CIVIL SERVICE AND THE CHALLENGES OF PRODUCTIVITY AND EFFICIENT SERVICE DELIVERY}

The public service is well placed to carry out its assigned tasks and responsibilities because, in analytic terms, its rational characteristics represent a shield from arbitrariness and undue interference. However, the performance of the civil service is significantly influenced by three broad relations forged with (i) political office holders, (ii) the larger public who are the object of government policy and (iii) the dialectics of relations within the service itself.

The role of political office holders or those who occupy elective or appointive political posts at all levels of government is clearly defined by the constitution. The executive arm of government has the main task of determining the policies and programmes of government at the relevant level. It sees to the general direction of the polity. In a democratic setting, such as what is being built under the current dispensation, the legislature is also critical. It not only performs oversight functions, but also plays the major role of law making. In making policies, and in deciding on the day-to-day matters of the state, both the executive and the legislature are clearly required to adhere to the rule of law and due process. Public expenditure must be within what is appropriated. The bureaucracy must not also be interfered with not only in regard to the principles guiding its conduct, but also in the discharge of its duties.

However, major frictions often do occur. Some are open but most remain hidden between political and administrative functionaries with serious implications for development. The principal cause of manifest and latent conflict is the non-adherence to powers and responsibilities granted each body by the law. It is no longer news to hear of interference by especially the executive arm of government in a purely administrative sphere of the state. This is typical in matters related to recruitment, placement, promotion and discipline of staff, award of contracts and so on. The question can validly be raised as to how far has any of the above been based purely on merit and in accord with the provisions of the public services rules and financial regulations?

Undue politicization of the civil service, contrary to established guidelines and procedures, is also a source of conflict. There is also the strangling of the civil service of the needed resources especially funds with which to carry out its assignments. The norm that relevant bureaucratic agencies can incur expenditure once budget have been passed has continued to be eroded. Other issues of contention are the apparent lack of conducive work environment and poor condition of service. The wages of a fresh graduate employee of the public service can hardly guarantee the satisfaction of his basic needs. Many cases of sharp practices can be linked to this basic problem.

Yet, as Maslow (1943) has argued, meeting workers' basic needs is a prerequisite for efficient performance. This has also been well-recognized in the charter for public service in Africa. Differences also arise over the propriety or otherwise of the actions or inactions of particularly political office holders. This often results in the undermining of the position of the other. The above are substantive issues at the centre of the relationships of civil servants and political office holders.

The relation of the civil service and political office holders, on the one hand, and the public or civil society on the other, seem to be one of distrust. There is the growing expectation of the public to the key bodies of government. Poverty is deep rooted, with some $70 \%$ of the population affected. Basic infrastructure and requirements of life, such as clean potable water, primary health care, roads, electricity and so on are either inadequate or non-existent for the bulk of the citizenry. Even security of life and property has become a major challenge. Public confidence on the capacity and will of political office holders and civil servants to attend to the 
above seem to be waning. Today, an average citizen sees the political and key civil servant as appropriating more than their due share of public resources. They are seen as corrupt and inefficient in the task of service delivery to the people. Little wonder there is the emerging dangerous trend of key public functionaries besieged everywhere by weak elements of the society to collect from them their "share" of the state resources!

The pattern of interpersonal relations within the civil service also involves disagreement. This is obvious; it is a social setting where people differ in terms of values and interests though bound by the common bond of work relationships (Albrow, 1978). Conflicts within the hierarchical nature of the civil service cannot be wished away. But the commonest source of conflict is over condition of service, work environment and the conduct of work. Where there is a sense of "colleagues" being unfairly treated in order to favour chosen ones, unconnected to merit and seniority; civility which should guide the relations of colleagues-junior or senior-is eroded. Yet successful group work depends to a large extent on the interpersonal relations among the members of an organization.

In essence, conflicts do occur over a number of issues and may take several forms. Regardless of their nature and intensity, they have serious implications for the development process. Development programmes are not implemented as a result or bureaucratic bottlenecks are allowed to thwart such policies. What is therefore the way forward for improving human relations and making the civil service a more efficient way? The next section addresses this.

\section{TOWARDS A MORE PRODUCTIVE AND SERVICE-ORIENTED CIVIL SERVICE}

One of the greatest requirements for enhanced mutual working relations between the public, political office holders and career civil servants is for each to respect the boundaries of the other. Both political office holders and bureaucrats have specific powers and responsibilities assigned to them by the relevant laws and guidelines. This should be adhered to. Today, we do not know how many appointments are based on merit, how many transfers, retirements or dismissals are fair and in accord with the law, how much of the lavish wealth displayed by politicians and even civil servants is judiciously earned? Clearly, it must be an issue of public concern: what resources are meant for the common must be utilized as such. Political office holders as well as top civil servants need to fully act on the basis of fairness and merit (including representativeness).

Misuse and abuse of power by any could and often leads to friction. This is very significant especially in the context of an environment which is not innocent of misappropriation of public funds, imprudent political and economic decisions in the allocation of scarce but allocatable resources, erosion of the rights of individuals and the conspicuous consumption of a few amidst the abject poverty of the masses, among others.

Interest in the welfare of the generality of the workers must also be sustainably generated. The use of human relations approach is key in this regard. It correlates efficiency with the welfare of workers and of their attitudes toward managements and their work groups (Singer, 1990:10, 89). It advocates the design of jobs which lead to social need gratification for workers, including the use of non-authoritarian leadership styles by superiors and the fostering of effective work group relations. It postulates that the interest of workers in terms of the basic concern for their physical and psychological needs is key. This is to avoid a frustrated and dissatisfied workforce that performs at minimal standards. It also lessens the chance of workers strikes. Of course, a look at the condition of work environment is also important: optimal 
performance must not be expected in an environment devoid of basic infrastructure and working tools, to take a few examples.

There is the question of checking the excesses of politicians when necessary. Ordinarily, this is the responsibility of the legislature. However, the career civil servants also have a role here. They have the power to advise and turn down requests and/or directives that are contrary to established guidelines. The career public servants must strive to carry out this part of their responsibilities diligently. This is especially in areas where their powers vis-à-vis that of political office holders are clearly delineated. They should be able and courageous enough to tell the executives where their powers begin and end. Many may wonder whether, in the face of enormous powers wielded by political office holders, a career civil servant could turn down such a request from, for example, a governor. The hard fact is that this is possible provided of course that the career civil servant is principled, uncorrupted and absolutely dedicated to service. But where career civil servants compete with political office holders in the diversion of funds for private purposes, they could not check any ones excesses. On the contrary, they would only remain the willing tools of political office holders.

There were classic examples where this role of the civil servant has been demonstrated. An example is worth citing here. The former Governor-General of the Northern Region Gen. (rtd) Hassan Usman Katsina, of blessed memory applied for a plot of land to build a house. His application was considered inappropriate by virtue of his office and the application was turned down and he took it. (Gboyega and Abubakar, 1989:10). Today, the frequency and speed with which such applications are made is hardly hidden.

In trying to "handle" the political office holders, the career civil servants must for their part understand their main responsibilities in relation to the executive. They are not politicians and must be non-partisan. The implication of this is that they must serve faithfully the government of the day. Not only this, they must tender advise and place all information and expertise available for the government to succeed. Breach of these guidelines not only weakens the relations between the two but should also attract sanctions. They must also work hard to translate policies in to concrete realities. Facilitating improvement in the living conditions of the people through effective policy implementation is the surest way to regain the confidence of the public.

Ultimately, the surest way for a more efficient and service oriented civil service is for all the stake holders to cooperate and positively partner for development to occur. Of course, people differ in terms not only of ideas, values and interests but also in the kind of work they partake in. But these kinds of differences are not, in reality, a hindrance to progress. The quest for socio-economic and political development constitutes a common ground for cooperation. Indeed, Durkheim (1858-1917) argued that as people become more specialized and different, they grew more dependent on one another. Durkheim (cited in Kamenka, et al, 1979) called this sort of solidarity 'organic solidarity', because society functioned as a complex entity that depended on the proper functioning of a variety of parts, or organs. Sociologists have also drawn attention to the importance of group membership precisely because most of us live with "one or more individuals with whom we share some sense of identity or common goals and with whom we interact in a specific social structure" (Mclyntyre, 2002: 118).

Finally, in this section, it is important to draw lessons from local, national and regional experiences concerning the need for a productive civil service. Tradition of excellence in service is deeply rooted in the Sokoto area, dating back to the period of jihad. The prime place of merit, to give an example, is demonstrated when Sheikh Abdullahi bn Fodio wrote that the appointment of a good candidate in the presence of a better one is not only a sin but null, void 
and of no effect. It is also on record that Sultan Muhammad Bello, then Head of the Caliphate appeared to give evidence before a public judicial officer, a conduct demonstrating the esteem with which transparency, accountability and respect for the rule of law were held in the Caliphate. Indeed, so important were the ethical traits of the caliphate that colonialism only established its firm roots following the erosion of these values by the later generation of the leaders and workers of the Caliphate (Aliyu, 1982).

The colonial civil service, even with its limitations, bequeathed to us some positive values such as observance of standards, values and ethics of work as well as diligence and hard work, among others. And those values have served to produced finest cream of civil servants spread across the country, who up till today, represent shining examples of professionalism, dedication, hard work and incorruptibility.

The Nigerian civil service should also draw lessons from the continent-wide efforts at enhancing professionalism and ethics in the public service. The "charter for the public service in Africa", approved at the third Pan African Conference of Public Service Ministers held at Windhoek (Namibia) in 2001 is particularly important in this regard. The charter gave concrete expression to the commitment of African states to define the principles that would promote transparency, professionalism and ethical standards in the African public services. They include the following (i) the principle of equality of all before the law without any distinction whatsoever, (ii) the principle of neutrality or the non-discrimination against employees on grounds of personal traits, (iii) the principle of complete adherence to the rule of law, and (iv) the principle of continuity or permanence in the public service.

Of importance also are the international rules governing relations between the public service and service users. Key issues here involve unrestricted access to service by intended beneficiaries, the involvement of users in the formulation and execution of relevant policies and programmes through broad consultations, the need for qualitative, effective and efficient service delivery, continuous review in the public service to enable it respond to ever-changing needs of the people and the need for transparency and accountability to the people.

The charter for the public service if Africa also defined the relation of public service to its employees. It stresses for recruitment and promotion to be based on competence, the need to address the aspirations of employees, the need for fair remuneration, physical safety, conducive work conditions and security of tenure, among others. For their part, employees are required to perform their tasks professionally and efficiently, displaying such traits as personal discipline, dignity, integrity, equity, impartiality, fairness, public spiritedness and courtesy. This is in addition to being politically neutral and avoiding conflict of interest.

The foregoing are important issues which the Nigerian public service can neglect only to its peril.

\section{CONCLUSION}

The civil service is a unique body that is well placed to play a major role in the effective functioning of any government. It is the "action" part of government and its shield in times of crises. It is not in contest that development, in all its multifaceted nature, can hardly occur without this important organ of government. Cooperation among all stake holders has become more imperative today than perhaps at any period before. This cooperation is necessary in order to arrest the disruption and confusion engendered by the sustained military dominance of the policies and management of the country as well as undue interference from especially political office holders. Harmonious working relations are also a prerequisite for lessening the incidence 
of conflict and stemming the tide of the collapse of public institutions. For the people, workers inclusive, they expect fulfillment of promises of motorable roads, potable water, good hospitals, better housing, and support for agriculture. While on the one hand the modern state today requires for it's functioning an efficient and effective service, the civil service on the other hand need the active support, respect and cooperation of government for it to perform. A number of fundamental things need to be given due attention: equity, social justice and so on from the two sets of public servants. They would neither be supported nor respected if they are seen to build empires for themselves and ignore the basic needs of others.

\section{References}

[1] Aliyu A. Y. (1982), Return to Civilian Rule. ABU Zaria (The Proceedings of the National Conference on Return to Civilian Rule, Held at the Institute of Administration, Ahmadu Bello University, Zaria, $26^{\text {th }}-30^{\text {th }}$ May, 1980).

[2] Albrow M. (1978), Bureaucracy, London: Macmillan

[3] Bande T. M. (1997), "Preparing the Zamfara State Civil Service for the $21^{\text {st }}$ Century" Paper presented at a Workshop on 'Enhancing Efficiency and Productivity in the Civil Service"

[4] CAFRAD, (2001), Charter for the Public Service in Africa, Editions, Rabat: OKAD.

[5] Gboyega A., Abubakar Y. (1989), "Nigerian Public Administration in Perspective" in Gboyega, et.al. (ed)., Nigeria Since Independence: The first 25 years, vol. III Ibadan: Heinemann.

[6] Maslow A. H. (1943), “A Theory of Human Motivation”, Psychological Review.

[7] Mclntyre L. J. (2002), The Practical Skeptic: Core Concepts in Sociology. Boston: McGraw-Hill.

[8] Mill J. S. (1964), Utilitarianism, Liberty, Representative Government, London: Everyman Reprint.

[9] Singer M. G. (1990), Human Resources Management. Boston: PWS-KENT.

[10] Weber, Marx, (1964), The Theory of Social and Economic Organization, New York: The Free Press of Glencoe.

[11] Kamenka E., Krygier M. (1979), Bureaucracy: The Career of a Concept, London: Edward Arnold. 